\title{
48. HYDROGEN- AND CARBON-ISOTOPE COMPOSITIONS OF METHANE FROM DEEP SEA DRILLING PROJECT SITE 618, ORCA BASIN ${ }^{1}$
}

\author{
Roger A. Burke, Jr. and William M. Sackett, University of South Florida \\ and \\ James M. Brooks, Texas A\&M University ${ }^{2}$
}

\begin{abstract}
Hydrogen- and carbon-isotope compositions of methane ( $\delta \mathrm{D}-\mathrm{CH}_{4}$ and $\left.\delta^{13} \mathrm{C}-\mathrm{CH}_{4}\right)$ and pore water hydrogen-isotope compositions $\left(\delta \mathrm{D}-\mathrm{H}_{2} \mathrm{O}\right)$ in several samples from the uppermost $100 \mathrm{~m}$ of Orca Basin sediments show little variation with depth and have mean values of $-184,-73.5$, and $7 \%$, respectively. The $\delta \mathrm{D}-\mathrm{CH}_{4}$ is typical of that generally found in deep-sea sediments and suggests that the methane was produced biologically almost entirely via the $\mathrm{CO}_{2}$ reduction pathway. Production of small amounts of methane $(\sim 15 \%$ of the total) from acetate dissimilation cannot be completely ruled out, however. The pore water is more enriched in deuterium than present day Gulf of Mexico deep water, suggesting that the brine found at the bottom of Orca Basin was formed at a time when appreciably more isotopically light water was tied up in continental ice sheets than is at present. The $\delta^{13} \mathrm{C}_{-} \mathrm{CH}_{4}$ values reported here are similar to previously determined brine $\delta^{13} \mathrm{C}-\mathrm{CH}_{4}$, but substantially more enriched in ${ }^{13} \mathrm{C}$ than previously determined pore water $\delta^{13} \mathrm{C}$ $\mathrm{CH}_{4}$. Isotopic evidence and the decrease in interstitial salinity with depth suggest that most of the methane production within the Orca Basin system occurs in sediments deeper than about $5 \mathrm{~m}$ sub-bottom. Small deposits of isotopically anomalous methane occurring in near-surface sediments may be the result of spatially variable inputs of slumped material to the sediments underlying the anoxic, hypersaline brine.
\end{abstract}

\section{INTRODUCTION}

Orca Basin is a $400-\mathrm{km}^{2}$ depression on the Louisiana continental slope located in a region where salt diapirism and slumping have created a complex seafloor morphology (Lehner, 1969; Shokes et al., 1977; Intraslope Basin Introduction and Summary, this volume). Dissolution by seawater of a near-surface salt deposit on the basin flank apparently accounts for the 200-m-thick layer of anoxic, hypersaline $(\sim 250 \mathrm{~g} / \mathrm{kg})$ water that occupies the bottom of the basin (Shokes et al., 1977; Wiesenburg, 1980). The brine is near saturation with respect to $\mathrm{NaCl}$ and is enriched in dissolved sulfate $(47.2 \mathrm{mM})$ relative to deep Gulf of Mexico seawater (D. Sheu, pers. comm., 1985). The dense brine is highly stable and mixes very slowly with the overlying seawater. As a result, methane produced in the underlying sediments (Sackett et al., 1979) has accumulated in the brine to a concentration six orders of magnitude greater than in the overlying deep Gulf seawater (Wiesenburg, 1980).

From consideration of seismic reflection profiles, geotechnical and clay mineralogical properties, and high sedimentation rates $(\sim 1 \mathrm{~m} / 1000$ yr.), Tompkins and Shephard (1979) concluded that slumping of basin flank sediments, both from within and from outside the area covered by brine, is the primary mechanism of sediment accumulation in the central part of the basin and that the amount and origin of slumped material varies spatially within the basin. Near-surface basin sediments originally deposited under anoxic conditions are enriched in to-

\footnotetext{
1 Bouma, A. H. Coleman, J. M., Meyer, A. W., et al., Init, Repts. DSDP, 96: Washington (U.,.S. Govt. Printing Office).

(1) Department of Marine Science, University of South Florida, 140 Seventh Avenue South, St. Petersburg, FL 33701; (Brooks) Department of Oceanog. raphy, Texas A\&M University, College Station, TX 77843.
}

tal organic carbon by a factor of 2 to 3 over normal slope sediments and contain large pieces of undecomposed Sargassum (Sackett et al., 1979; Northam et al., 1981). These observations suggest a high degree of preservation of organic matter in Orca Basin sediments resulting from reduced rates of biodegradation caused by the hypersalinity (Sackett et al., 1979) and/or the anoxic conditions (Northam et al., 1981).

Methane associated with present day marine sediment is formed by both microbial and thermal decomposition of buried organic matter. Microbial processes account for most of the methane production in typical near-surface $(<1 \mathrm{~km}$ depth) marine sediment because this sediment rarely attains sufficiently high temperatures to permit significant thermocatalytic methane production. Microbial formation of methane in natural environments is thought to occur mainly via two pathways, $\mathrm{CO}_{2}$ reduction and acetate dissimilation (Zehnder, 1978). In freshwater sediments, acetate dissimilation is believed to be the dominant pathway, accounting for 60 to $70 \%$ of the methane production (Mah et al., 1977). In contrast, methane production in deep-sea sediments is thought to occur almost exclusively via $\mathrm{CO}_{2}$ reduction (Claypool and Kaplan, 1974; Schoell, 1980).

We present here $\delta \mathrm{D}-\mathrm{CH}_{4}, \delta \mathrm{D}-\mathrm{H}_{2} \mathrm{O}$, and $\delta^{13} \mathrm{C}-\mathrm{CH}_{4}$ of samples obtained from various sub-bottom depths at Deep Sea Drilling Project Site 618. This site was located near the center of the northern sub-basin of Orca Basin (Fig. 1), approximately $2 \mathrm{~km}$ from the location studied earlier by Sackett et al. (1979).

\section{METHODS}

Samples of gas from expansion pockets which developed within the cores upon core retrieval were transferred to vacutainers on board ship (Explanatory Notes, this volume) and forwarded to our laboratory for isotopic analyses. 


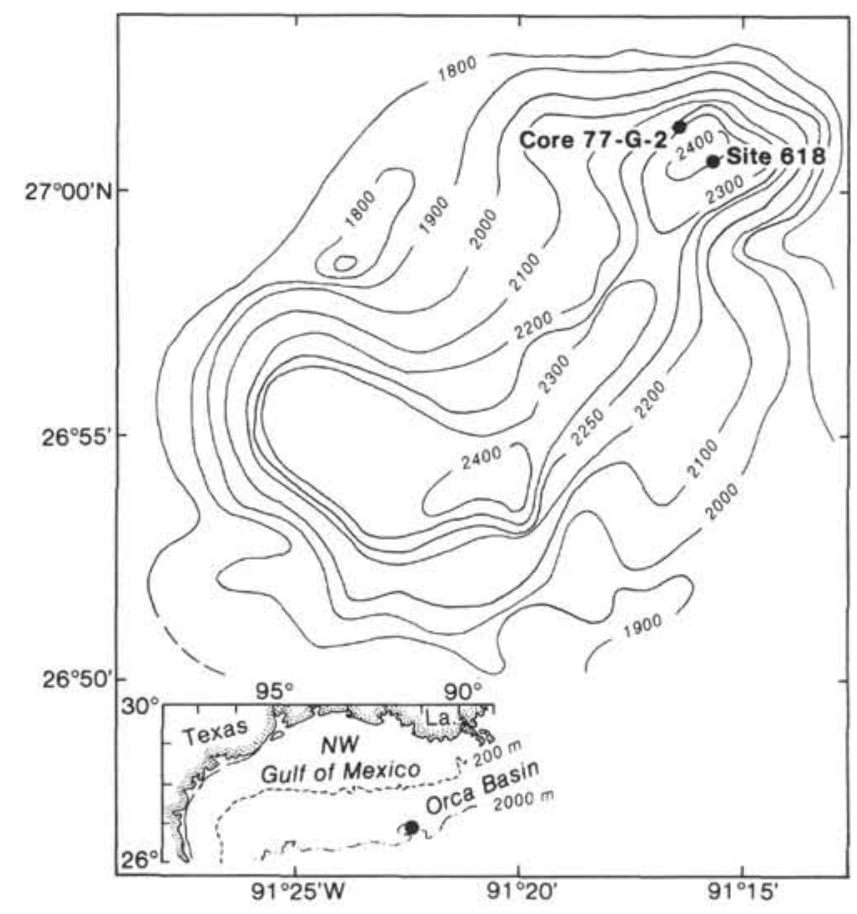

Figure 1. Bathymetric map of Orca Basin showing the locations of Site 618 and the piston core (77-G-2, Station 24) studied by Sackett et al. (1979).

Preparation of methane for isotopic analyses involved gas chromatographic (GC) separation of methane from other gases followed by combustion to $\mathrm{CO}_{2}$ and water in a vacuum line. Methane was combusted in a cupric oxide furnace $\left(\sim 850^{\circ} \mathrm{C}\right)$, to which 5-10 torr of oxygen had been added, as it was swept through by the GC carrier gas. Excess oxygen and helium were then pumped away and the $\mathrm{CO}_{2}$ and water cryogenically separated $\left(\sim-90^{\circ} \mathrm{C}\right)$ in the vacuum line. The $\delta^{13} \mathrm{C}$ of the $\mathrm{CO}_{2}$ was then measured using a Finnigan MAT 250 isotope ratio mass spectrometer (IRMS). The water from the combustion was reduced to hydrogen gas using the zinc metal method (Coleman et al., 1982 ) and analyzed with the IRMS. The GC used was a Hewlett-Packard $5710 \mathrm{~A}$ equipped with a thermal conductivity detector and two 6$\mathrm{mm}$ OD stainless steel columns ( $3 \mathrm{~m}$ grade 12 silica gel and $2 \mathrm{~m}$ molecular sieve 5A) connected in series through a Valco ten-port valve. Helium carrier flow was $50 \mathrm{ml} / \mathrm{min}$ and the oven temperature held constant at $90^{\circ} \mathrm{C}$. Hydrogen- and carbon-isotope compositions are reported relative to standard mean ocean water (SMOW) and PeeDee belemnite (PDB), respectively, using the standard notation:

$$
\delta\left(\%_{0}\right)=\left(\frac{R \text { (sample })}{R \text { (standard })}-1\right) \times 1000
$$

where $R$ is $\mathrm{D} / \mathrm{H}$ and ${ }^{13} \mathrm{C} /{ }^{12} \mathrm{C}$, respectively. Based on repeated analyses of a methane standard, analytical reproducibility of the procedure is calculated to be 1.5 and $0.2 \%$ (one standard deviation) for $\delta \mathrm{D}-\mathrm{CH}_{4}$ and $\delta^{13} \mathrm{C}-\mathrm{CH}_{4}$ determinations, respectively.

Interstitial water samples (IWGA) were reduced to hydrogen gas using the zinc metal method (Coleman et al., 1982) and analyzed with the IRMS. Based on repeated analyses of two water standards, the analytical reproducibility of this procedure is calculated to be $1.5 \%$ (one standard deviation).

\section{RESULTS AND DISCUSSION}

The results of our isotopic analyses of Site 618 interstitial methane and water are presented in Table 1 . The $\delta \mathrm{D}-\mathrm{CH}_{4}$ values show essentially no variation with depth and fall within the relatively narrow range of values $(-170$ to $-190 \%)$ generally measured in other DSDP
Table 1. Hydrogen- and carbon-isotope compositions of methane and pore water hydrogen-isotope compositions in several samples from Site 618.

\begin{tabular}{|c|c|c|c|c|}
\hline Core-Section & $\begin{array}{l}\text { Sub-bottom } \\
\text { depth (m) }\end{array}$ & $\underset{(\% 0)}{\delta \mathrm{D}-\mathrm{H}_{2} \mathrm{O}}$ & $\underset{\left(\% 0_{0}\right)}{\delta \mathrm{D}-\mathrm{CH}_{4}}$ & $\underset{\left({ }^{13}{ }^{13} \mathrm{C}_{0}-\mathrm{CH}_{4}\right.}{ }$ \\
\hline $1-2$ & 3 & 5 & & \\
\hline $1-3$ & 4.5 & & -181 & -74.9 \\
\hline $2-4$ & 12 & 8 & & \\
\hline $3-2$ & 19 & 8 & & \\
\hline $3-5$ & 24 & & -186 & -73.3 \\
\hline $4-2$ & 28 & 8 & & \\
\hline $4-6$ & 34 & & -185 & -73.1 \\
\hline $5-5$ & 42 & 8 & & \\
\hline $5-7$ & 45 & & -184 & -72.8 \\
\hline $7-1$ & 52 & 7 & & \\
\hline $7-3$ & 54 & & -186 & -72.6 \\
\hline $8-1$ & 58 & 5 & & \\
\hline $8-5$ & 64 & & -185 & -72.7 \\
\hline $9-2$ & 73 & 5 & -184 & -72.7 \\
\hline $11-1$ & 90 & 5 & & \\
\hline $11-2$ & 92 & & -181 & -75.7 \\
\hline Mean & & 7 & -184 & -73.5 \\
\hline
\end{tabular}

sediments (Schoell, 1983) where $\mathrm{CO}_{2}$ reduction is thought to account for most of the biological methane production (Claypool and Kaplan, 1974). Based largely on the results of Nakai et al. (1974) and Schoell (1980), Woltemate et al. (1984) have developed a model of biogenic methane formation in which the $\delta \mathrm{D}$ of methane produced solely via $\mathrm{CO}_{2}$ reduction (Eq. 1) and acetate dissimilation (Eq. 2), respectively, is related to $\delta \mathrm{D}-\mathrm{H}_{2} \mathrm{O}$ by the following equations:

$$
\begin{aligned}
& \delta \mathrm{D}-\mathrm{CH}_{4}=\delta \mathrm{D}-\mathrm{H}_{2} \mathrm{O}-(160 \pm 10) \% 0 \\
& \delta \mathrm{D}-\mathrm{CH}_{4}=0.25 \delta \mathrm{D}-\mathrm{H}_{2} \mathrm{O}-364 \% 0
\end{aligned}
$$

Application of the Woltemate et al. (1984) model to the data presented here (Table 1) suggests that the acetate dissimilation pathway could account for $15 \%$ of the total methane production in Orca Basin sediments. Whelan et al. (this volume) report a pore-water acetate concentration of $1 \mathrm{mM}$ at $15-\mathrm{m}$ sub-bottom depth at Site 618. This concentration is about a factor of two higher than the $K_{\mathrm{m}}$ (substrate concentration at which initial reaction velocity is half maximal) for the acetate-decarboxylating methane bacterium Methanobacterium soehngenii, which was isolated from digested sewage sludge (Zehnder et al., 1980). Recently, isolation of a new acetotrophic marine methane-producing bacterium, Methanosarcina acetivorans, from methane-evolving sediments was reported by Sowers et al. (1984). If an acetotrophic methanogen inhabits the Orca Basin sediments, and if its $K_{\mathrm{m}}$ is similar in magnitude to that of Methanobacterium soehngenii, then some production of methane from acetate, at least at $15-\mathrm{m}$ depth, should be possible.

The preceding argument assumes that a significant fraction of the acetate detected is "microbiologically available," a condition that may or may not be met. At 15-m sub-bottom depth, at Site 618, the interstitial salinity was about $115 \% 0$ (Site 618 chapter, this volume). Methanosarcina acetivorans exhibits a maximum specific growth rate at about $0.2 \mathrm{M} \mathrm{NaCl}$ concentration; the growth rate decreases rapidly with increase in $\mathrm{NaCl}$ concentration 
(Sowers et al., 1984). Thus, any acetotrophic methanogens living at $15-\mathrm{m}$ depth may be inhibited by the high salinity. This observation would agree with the suggestion of Sackett et al. (1979) that the rate of overall organic matter destruction may be slowed by the hypersalinity. Thus, while acetate dissimilation may account for a small percentage of the methane production in Orca Basin sediments, most of the methane probably results from $\mathrm{CO}_{2}$ reduction.

The salinity (Site 618 chapter, this volume) and $\delta \mathrm{D}-$ $\mathrm{H}_{2} \mathrm{O}$ (Table 1) profiles for Site 618 suggest that the Orca Basin brine has a $\delta \mathrm{D}-\mathrm{H}_{2} \mathrm{O}$ of about $4 \%$. This is heavier than present day Gulf Basin water $(\delta \mathrm{D}=0.7$ to $1.1 \%$; Frank, 1973) and suggests that the Orca Basin brine was formed sometime between the last glacial maximum $(18,000$ yr. ago, McIntyre et al., 1976) and the end of the subsequent deglaciation period $(\sim 14,000-5,000$ yr. ago, Barry et al., 1979) when significant quantities of isotopically light water (Dansgaard and Tauber, 1969) were tied up in continental ice sheets. It has been estimated that ocean deep waters were about 1.2 (Dansgaard and Tauber, 1969) to $1.65 \% 0$ (Shackleton, 1977) enriched in ${ }^{18} \mathrm{O}$ at the last glacial maximum relative to present day deep water. This would correspond to a deuterium enrichment of about 8 to $11 \%$, assuming the deuterium to ${ }^{18} \mathrm{O}$ relationship for North Atlantic Surface Water of Craig (1967) applies. If these estimates of the deep ocean isotopic fractionation and the brine $\delta \mathrm{D}(4-5 \%)$ are accurate, then the age of the Orca Basin brine might be further constrained to the deglaciation period $(14,000-5,000$ yr. ago). In support of this, the estimate of Addy and Behrens (1980) for when the brine began to accumulate in the basin (about 8,000 yr. ago) falls within this range of time. However, there is some uncertainty about how much the sea level was actually lowered during the last glacial maximum. Blackwelder et al. (1979) have estimated that substantially less ice was present from 17,000 to 10,000 yr. ago than would be expected from the estimates of minimum sea level employed by Dansgaard and Tauber (1969) and Shackleton (1977).

The interstitial methane $\delta^{13} \mathrm{C}$ values reported here (Table 1) and by Pflaum et al. (this volume) are similar to values reported by Sackett et al. (1979) for $\delta^{13} \mathrm{C}$ of methane dissolved in the brine $(-74.5$ to $-72 \%)$, but quite different from interstitial methane $\delta^{13} \mathrm{C}(-105$ to $-85 \%)$ compositions reported by Sackett et al. (1979). Very light $\left(\delta^{13} \mathrm{C}<-90\right)$ methane has not been widely encountered in sediments sampled by DSDP (Claypool and Kvenvolden, 1983). When very ${ }^{13} \mathrm{C}$-depleted methane is found, it usually occurs at the base of the sulfate-reduction zone, generally acknowledged to be the shallowest depth of rapid production and significant accumulation of methane in deep-sea sediments (Claypool and Kvenvolden, 1983). In general, very ${ }^{13} \mathrm{C}$-depleted methane is probably not of great quantitative significance in deep-sea sediments and may only result under certain organic geochemical and/or sedimentological conditions. Because the amount and origin of slumped sediments varies spatially within the basin (Tompkins and Shephard, 1979), the sediments cored by Sackett et al. (1979) could be quite different from those cored at Site 618. Sackett et al. (1979) gave a water depth of $2340 \mathrm{~m}$ for their core location; this depth is $80 \mathrm{~m}$ shallower than at Site 618 and may actually be on the basin flank (Fig. 1). Consideration of the probable sediment variability and all of the isotopic data suggests that the very light sedimentary methane sampled by Sackett et al. (1979) is just a localized, near surface occurrence that is not isotopically representative of the methane component of either the Orca Basin brine or pore waters. Between the brine/sediment interface and about $30 \mathrm{~m}$ sub-bottom depth the interstitial salt content decreases from brine levels to values more characteristic of normal marine sediments (Site 618 chapter, this volume). Rapid methane production in sediment layers less influenced by high salinity effects and subsequent upward diffusion probably provides most of the methane dissolved in the brine.

\section{ACKNOWLEDGMENT}

Financial support for this work was provided by National Science Foundation grant \#OCE-8308945 from the Marine Chemistry Program, Oceanography Section. This manuscript was reviewed by K. Kvenvolden and G. Claypool.

\section{REFERENCES}

Addy, S. R., and Behrens, E. W., 1980. Time of accumulation of hypersaline anoxic brine in Orca Basin (Gulf of Mexico). Mar. Geol., 37:241-252.

Barry, R., Fritts, H., Imbrie, J., Kutzbach, J., Mitchell, J. M., and Savin, S. M., 1979. Paleoclimatic research: status and opportunities. Quat. Res., 12:6-17.

Blackwelder, B. W., Pilkey, O. H., and Howard, J. D., 1979. Late Wisconsin sea levels on the southeast U.S. Atlantic shelf based on in-place shoreline indicators. Science, 204:618-620.

Claypool, G. E., and Kaplan, I. R., 1974. The origin and distribution of methane in marine sediments. In Kaplan, I. R. (Ed.), Natural Gases in Marine Sediments: New York (Plenum Press), pp. 99-139.

Claypool, G. E., and Kvenvolden, K. A., 1983. Methane and other hydrocarbon gases in marine sediments. Ann. Rev. Earth Planet. Sci., 11:299-327.

Coleman, M. L., Shepherd, T. J., Durham, J. J., Rouse, J. E., and Moore, G. R., 1982. Reduction of water with zinc for hydrogen isotope analysis. Anal. Chem., 54:993-995.

Craig, H., 1967. Ocean water, isotopic composition of. McGraw-Hill Yearbook of Science and Technology: New York (McGraw-Hill), pp. 268-271.

Dansgaard, W., and Tauber, H., 1969. Glacier oxygen-18 content and Pleistocene ocean temperatures. Science, 166:499-502.

Frank, D. J., 1973. Deuterium distribution in the Gulf of Mexico. J. Phys. Oceanogr., 3:230-236.

Lehner, P., 1969. Salt tectonics and Pleistocene stratigraphy on continental slope of northern Gulf of Mexico. Am. Assoc. Pet. Geol. Bull., 53:2431-2479.

McIntyre, A., Kipp, N. G., Be, A. W. H., Crowley, T., Kellogg, T., Gardner, J. V., Prell, W., and Ruddiman, W. F., 1976. Glacial north Atlantic 18,000 years ago: A CLIMAP reconstruction. Mem. Geol. Soc. Am., 145:43-76.

Mah, R. A., Ward, D. M., Baresi, L., and Glass, T. L., 1977. Biogenesis of methane. Ann. Rev. Microbiol., 31:309-341.

Nakai, N., Yoshida, Y., and Ando, N., 1974. Isotopic studies on oil and natural gas fields in Japan. Chikyu Kagaka, 7/8:87-98.

Northam, M. A., Curry, D. A., Scalan, R. S., and Parker, P. L., 1981. Stable carbon isotope ratio variations of organic matter in Orca Basin sediments. Geochim. Cosmochim. Acta, 45:257-260.

Sackett, W. M., Brooks, J. M., Bernard, B. B., Schwab, C. R., Chung, H., and Parker, R. A., 1979. A carbon inventory for Orca Basin brines and sediments. Earth Planet Sci. Lett., 44:73-81.

Schoell, M., 1980. The hydrogen and carbon isotopic composition of methane from natural gases of various origins. Geochim. Cosmochim. Acta, 44:649-661. 
1983. Genetic characterization of natural gases. Am. Assoc. Pet. Geol. Bull., 67:2225-2238.

Shackleton, N. J., 1977. The oxygen isotope stratigraphic record of the Late Pleistocene. Philos. Trans. R. Soc. London, Ser. B, 280: 169-182.

Shokes, R. F., Trabant, P. K., Presley, B. J., and Reid, D. F., 1977. Anoxic, hypersaline basin in the Northern Gulf of Mexico. Science, 196:1443-1446.

Sowers, K. R., Baron, S. F., and Ferry, J. G., 1984. Methanosarcina acetivorans sp. nov., an acetotrophic methane-producing bacterium isolated from marine sediments. Appl. Environ. Microbiol., 47:971-978.

Tompkins, R. E., and Shephard, L. E., 1979. Orca Basin: Depositional processes, geotechnical properties, and clay mineralogy of Holocene sediments within an anoxic, hypersaline basin, northwestern Gulf of Mexico. Mar. Geol., 33:221-238.
Wiesenburg, D. A., 1980. Geochemistry of dissolved gases in the hypersaline Orca Basin [PhD dissert.]. Texas A\&M University, College Station.

Woltemate, I., Whiticar, M. J., and Schoell, M., 1984. Carbon and hydrogen isotopic composition of bacterial methane in a shallow freshwater lake. Limnol. Oceanogr., 29:985-992.

Zehnder, A. J. B., 1978. Ecology of methane formation. In Mitchell, R. (Ed.), Water Pollution Microbiology (Vol. 2): New York (Wiley), 349-376.

Zehnder, A. J. B., Huser, B. A., Brooks, T. D., and Wuhrmann, K., 1980. Characterization of an acetate-decarboxylating, non-hydrogen-oxidizing methane bacterium. Arch. Microbiol., 124:1-11.

Date of Initial Receipt: 21 December 1984

Date of Acceptance: 2 July 1985 